\title{
NEW CORONAVIRUS IN PREgNANT WOMEN. Maternal and perinatal outcomes.
}

Jaime Sánchez ${ }^{\text {a }}$

Jorge Espinosa a

Luis Carlos Caballero ${ }^{b}$

Sara Campana B ${ }^{\mathrm{C}}$

Arelys Quintero $^{d}$

Carlos Luo ${ }^{\mathrm{C}}$

Jorge Ng $\mathrm{C}^{\mathrm{c}}$

Rafael de Gracia e

Paulino Vigil-De Gracia*

*Corresponding Author: Paulino Vigil-De Gracia, MD. Complejo Hospitalario Dr. AAM Caja de Seguro Social. Investigador distinguido del Sistema Nacional de Investigación, SENACYT Panamá, e-mail: pvigild@hotmail.com

a-Ginecología y Obstetricia, Hospital Santo Tomás, Panamá, Panamá.

b-Ginecología y Obstetricia, Hospital Luis “Chicho Fábrega”, Santiago-Veraguas, Panamá

c-Ginecología y Obstetricia, Complejo Hospitalario Dr. AAM CSS", Panamá, Panamá.

d-Ginecología y Obstetricia, Hospital José Domingo de Obaldía, David-Chiriquí, Panamá.

e- Ginecología y Obstetricia, Hospital San Miguel Arcangel, Panamá, Panamá. 


\section{ABSTRACT}

Objectives: To report the maternal and neonatal results of patients infected with COVID-19 in Panama.

Methods: The study is based on the analysis of pregnant women with COVID-19, in 5 hospitals in the Republic of Panama. The inclusion criteria were: Patients with or without symptoms, positive RT-PCR for SARS-CoV-2 in the period from March 23 to 6 months after, whose births were attended in one of those 5 hospitals and who signed the consent. Data was obtained at the time of diagnosis of the infection and at the time of termination of pregnancy for the mother and newborn.

Results: 253 patients met the inclusion criteria. Most were diagnosed in the third trimester (89.3\%). $10.3 \%$ of the patients presented in a severe form of COVID-19. The most frequent complication was pre-eclampsia and if we add gestational hypertension they represent $21.2 \%$; most of the patients terminated the pregnancy by caesarean section (58\%). $26.9 \%(95 \% \mathrm{Cl} 21.3-32.9 \%)$ of the births were premature, and perinatal mortality was $5.4 \%(95 \% \mathrm{Cl} 3.0-9.0 \%)$. There was a need for mechanical ventilation in $5.9 \%(95 \% \mathrm{Cl} 3.6-9.6 \%)$ of the cohort and there were four maternal deaths $(1.6 \%-95 \% \mathrm{Cl} 0.6-4.0 \%)$.

Conclusions: This study of pregnant women infected with COVID-19 and diagnosed with RT-PCR shows serious maternal complications such as high admission to the ICU, need for mechanical ventilation and one death in every 64 infected. Frequent obstetric complications such as hypertension, premature rupture of membranes, high rate of prematurity and perinatal lethality were also seen. 
medRxiv preprint doi: https://doi.org/10.1101/2021.06.03.21258328; this version posted June 6, 2021. The copyright holder for this preprint (which was not certified by peer review) is the author/funder, who has granted medRxiv a license to display the preprint in perpetuity. It is made available under a CC-BY-NC-ND 4.0 International license.

- key words: SARS-CoV-2 infection; pregnancy, premature rupture of membranes, maternal infection, neonatal complications, maternal lethality 


\section{INTRODUCTION}

Since the end of 2019 it has been detected in Wuhan-China, a viral infection whose causative agent was a new coronavirus, later identified as SARS-CoV-2; this viral disease led the World Health Organization to declare the COVID-19 pandemic for March $11^{1-3 .}$

One year after the appearance of this disease, much progress has been made in the knowledge of its epidemiological behavior, virology, genetics, clinical findings, lethality and affectation by age groups and baseline conditions of the population ${ }^{4}$. We have learned during this first year about the associated complications, risk of hospitalization, greater possibility of admission to an intensive care unit, greater possibility of mechanical ventilation and greater possibility of death ${ }^{5}$, in pregnant women with COVID-19. Furthermore, we know that its evolution is less severe than other respiratory diseases caused by coronavirus such as SARS and MERS ${ }^{6}$. High frequencies of cesarean sections, premature births, ruptures of membranes and other complications have been associated with COVID-19 ${ }^{7}$. From the neonatal side, prematurity, low weight and pneumonia are the most frequent findings ${ }^{5-7}$, vertical transmission has not been proved with certainty ${ }^{8}$ and perinatal transmission is slightly more frequent but its impact on neonatal health is mild ${ }^{9}$.

As time passes, more reports are made about the new coronavirus and pregnancy, but few reports are from third world countries and Latin America .It is necessary to know about the evolution and results that the SARS-CoV-2 infection produces around the world and thus have a more accurate knowledge of its global impact. 
Our objective is to report the findings and evolution of pregnant women with SARSCoV-2 in 5 main hospitals in the Republic of Panama during the first 6 months of the epidemic.

\section{MATERIALS AND METHODS}

We conducted a prospective and observational cohort study from the beginning of the epidemic in Panama (mid-March 2020) for a period of 6 months, in pregnant women with a diagnosis of SARS-CoV-2 confirmed by RT-PCR. Pregnant women with or without symptoms could be part of the study. Informed consent was required and the patients had to be admitted or delivered in one of the following hospitals: Complejo Hospitalario "Dr. AAM "Social Security Fund in Panama, Santo Tomás Hospital in Panama, José Domingo de Obaldía Hospital in Chiriquí, Luis" Chico "Fábrega Hospital in Veraguas and San Miguel Arcángel Hospital in Panama.

The sampling, processing, and laboratory techniques in patients with clinical suspicion, contacts, or specific indication were done following the national guidelines given by the ministry of health of Panama, which are those required by the World Health Organization.

Maternal data such as age, parity, symptoms, body mass index, comorbidities, gestational age at the onset of symptoms and at the end of pregnancy, severity of the disease, admission to the intensive care unit, need for mechanical ventilation and evolution were recorded. In addition, obstetric complications, cause of pregnancy termination, birth route, birth weight, APGAR at the first and fifth minute, time between the onset of symptoms and the termination of pregnancy were recorded. 
The protocol was approved by the national bioethics committee of Panama, protocol reference: EC-CNBI-2020-04-45.

The maternal baseline characteristics and the neonatal results are presented in absolute numbers, percentages with $95 \% \mathrm{Cl}$, means and standard deviation.

In view of incomplete data in some cases, absolute numbers were paired with total number of cases in which the information about the characteristic being studied was available. Statistical analysis was performed with Epi Info software version 7 (Centers for Disease Control and Prevention, Atlanta, GA).

\section{RESULTS}

Since March 23, when the first confirmed pregnant case was registered in Panama, up to 6 months later, 253 cases with positive SARS-CoV-2 by RT-PCR were registered (in the five hospitals), eleven (4.35\%) were abortions, 21 have not finished the pregnancy yet or were treated in other hospitals after their recovery. Maternal and birth data were obtained in 221 patients. Most participants started symptoms or were diagnosed in the third trimester (89.3\%), see more information in table1. $56.9 \%$ $(95 \% \mathrm{Cl} 50.8-62.9 \%)$ of the patients presented symptoms at the time of diagnosis, fever being the most common symptom, but in only $36 \%(95 \% \mathrm{Cl} 30.3-42.1 \%)$ of the cases; $10.3 \%(95 \% \mathrm{Cl} 7.1-14.6 \%)$ of the patients presented with severe disease, see table 1.

The most frequent complication was pre-eclampsia and if we add gestational hypertension they represent $21.2 \%$; most of the patients ended the pregnancy by cesarean section (58\%), however, in only $10.1 \%$ the indication was the disease itself (COVID-19), Table 2. 
In relation to births, a prematurity of $26.9 \%(59 / 221)$ was found, $12.2 \%(27 / 221)$ presented growth restriction or small for gestational age and perinatal mortality of $5.3 \%(12 / 227$, includes twins), predominantly intra-uterine death.

Antiviral treatment was only offered to $4 \%$ of the cohort and of them $75 \%$ was postbirth, see Table 2. There was a need for mechanical ventilation in 5.9\% (95\% Cl 3.6$9.6 \%)$ of the group and four of them died (1.6\%), table 2.

\section{DISCUSSION}

This is the first study from Panama and Central America and one of the few in Latin America on SARS-CoV-2 infection. The diagnosis of the infection is made predominantly in the third trimester, one in every 4 pregnant women has obesity as a risk factor, one third are asymptomatic, pre-eclampsia is the most frequent obstetric complication, one in ten presented the severe form of the disease and one in every 64 infected dies. There is a high frequency of prematurity, perinatal mortality is also high, and neonatal infection is rare.

Obesity is a known risk factor ${ }^{10}$ for becoming infected with SARS-CoV-2 and this

finding has also been reported in other studies of pregnant women ${ }^{11-12}$; we found that obesity is present as a risk factor in $24.9 \%$ of pregnant women and the average body mass index in the entire population is in overweight values $(28.4 \mathrm{~kg} / \mathrm{m} 2)$.

Another very interesting finding in our cohort is the gestational age at the time of making the diagnosis, $89 \%$ were more than 27 weeks of gestation; This finding is also reported in previous studies ${ }^{11-14}$; a greater possibility of maternal infection in the third trimester is evident. This is a finding that deserves a follow-up study to assess prognosis and complications according to the trimester of infection. So far it 
has not been analyzed in large cohorts, despite the fact that there appears to be a greater susceptibility to infection in the third trimester.

Surprisingly, we found that pre-eclampsia with or without severe form and gestational hypertension were diagnosed in one of every 5 patients with COVID-19. This finding represents twice that diagnosed in a population before COVID-19 ${ }^{15,16}$, in addition, this finding has not been reported in previous studies with COVID-19 ${ }^{11-}$ 14. Definitely, more research is needed on the possible relationship, association or imitation between pre-eclampsia and maternal infection by SARS-CoV-2 ${ }^{17}$, theoretically, it is possible to explain the greater presence of pre-eclampsia and gestational hypertension in pregnant women with COVID-19 ${ }^{18}$.

The severity, need to admit to the intensive care unit, need for mechanical ventilation and lethality is definitely higher in pregnant women with COVID-19 ${ }^{5,19}$. We found that the need to admit to intensive care units was $6.7 \%$, being lower than that reported in the USA ${ }^{5}$, but with a $5.9 \%$ possibility of endotracheal intubation which is double that reported in the USA, the lethality is similar to that reported in other latitudes ${ }^{5,12,14}$, and possibly lower than in brazil ${ }^{19}$.

Births before 37 weeks (prematurity) was found in $26.9 \%$ of the studied cohort, largely induced by the severity of the infection, and complications such as hypertension and premature rupture of membranes. Similar findings have been previously reported ${ }^{12,13,20}$, however, it is more than twice the risk of that reported in the UK ${ }^{11 .}$

The perinatal mortality found in this study $(5.3 \%)$ is very high compared to the UK, Wuhan and Sweden ${ }^{11,21}$, and similar to that reported in a multinational study ${ }^{14}$. The factor that contributes the most to mortality in our cohort is prematurity, since $67 \%$ 
$(8 / 12)$ were less than 28 weeks old at the time of birth.

The limitations of this survey is the type of study (simple survey); the study does not involve the entire population; short duration, it was only for a period of 6 months, newborns are not followed-up after birth and do not know the risk of neonatal infections.

The main strengths are the contribution for the country and obvious for Latin America regarding the experience and results of mothers with COVID-19 and their perinatal outcomes, all patients have RT-PCR confirming the diagnosis of SARS-CoV-2.

In summary, this observational cohort study conducted in Panama with COVID-19 patients diagnosed with RT-PCR shows a high percentage of maternal complications, high admission to the ICU and mechanical ventilation, with about $2 \%$ maternal death; in addition to obstetric complications such as hypertension, premature rupture of membranes, high rate of prematurity and perinatal lethality. At the time of birth (using for PCR diagnosis) neonatal infection with SARS-CoV-2 is very low. 


\section{AUTHORS CONTRIBUTIONS}

All authors contributed equally for study conception and study design. JS, JE, LCC, $A Q$ and $P V D$ were responsible for data collection. JS, JE, CL, JNC, RdG, PVD and SCB were responsible for data analysis and interpretation. JS, JE, and PVD wrote the first draft of the paper. All authors reviewed and provided comments on the first draft and approved the final manuscript. The corresponding author attests that all listed authors meet the authorship criteria and that no others meeting the criteria have been omitted.

\section{CONFLICT OF INTEREST}

The authors report no conflict of interest. 


\section{REFERENCES}

1- Li Q, Guan X, Wu P, Wang X, Zhou L, Tong Y, et al. Early Transmission Dynamics in Wuhan, China, of Novel Coronavirus-Infected Pneumonia. N Engl J Med. 2020;382(13):1199-1207. doi: 10.1056/NEJMoa2001316.

2- Bi Q, Wu Y, Mei S, Ye C, Zou X, Zhang Z, et al. Epidemiology and transmission of COVID-19 in 391 cases and 1286 of their close contacts in Shenzhen, China: a retrospective cohort study. Lancet Infect Dis. 2020;20(8):911-919. doi: 10.1016/S1473-3099(20)30287-5. Erratum in: Lancet Infect Dis. 2020;20(7):e148.

3- World Health Organization. WHO Director-General's opening remarks at the media briefing on COVID-19- 11 March 2020. Available from: https://www.who.int/dg/speeches/detail/who-director-general-s- openingremarks-at-the-media-briefing-on-covid-19---11-march-2020 (accessed 11 March 2020).

4- Dey A, Das R, Misra HS, Uppal S. COVID-19: Scientific Overview of the global Pandemic. New Microbes New Infect. 2020 Oct 28:100800. doi: 10.1016/j.nmni.2020.100800.

5- Zambrano LD, Ellington $S$, Strid $P$, et al. Update: Characteristics of Symptomatic Women of Reproductive Age with Laboratory-Confirmed SARSCoV-2 Infection by Pregnancy Status - United States, January 22-October 3, 2020. MMWR Morb Mortal Wkly Rep 2020;69:1641-1647. DOI: http://dx.doi.org/10.15585/mmwr.mm6944e3external icon 
6- Mullins E, Evans D, Viner RM, O'Brien P, Morris E. Coronavirus in pregnancy and delivery: rapid review. Ultrasound Obstet Gynecol. 2020;55(5):586-592. doi:10.1002/uog.22014

7- Capobianco G, Saderi L, Aliberti S, et al. COVID-19 in pregnant women: A systematic review and meta-analysis [published online ahead of print, 2020 Jul 16]. Eur J Obstet Gynecol Reprod Biol. 2020;S0301-2115(20)30446-2. doi:10.1016/j.ejogrb.2020.07.006

8- Wang C, Zhou YH, Yang HX, Poon LC. Intrauterine vertical transmission of SARS-CoV-2: what we know so far. Ultrasound Obstet Gynecol. 2020;55(6):724-725. doi:10.1002/uog.22045

9- Vigil-De Gracia P, Luo C, Epifanio Malpassi R. Perinatal transmission with SARS-CoV-2 and route of pregnancy termination: a narrative review [published online ahead of print, 2020 Jul 26]. J Matern Fetal Neonatal Med. 2020;1-5. doi:10.1080/14767058.2020.1788533.

10-Chu Y, Yang J, Shi J, Zhang P, Wang X. Obesity is associated with increased severity of disease in COVID-19 pneumonia: a systematic review and metaanalysis. Eur J Med Res. 2020 Dec 2;25(1):64. doi: 10.1186/s40001-02000464-9.

11-Adhikari EH, Moreno W, Zofkie AC, MacDonald L, McIntire DD, Collins RRJ, Spong CY. Pregnancy Outcomes Among Women With and Without Severe Acute Respiratory Syndrome Coronavirus 2 Infection. JAMA Netw Open. 2020 Nov 2;3(11):e2029256. doi: 10.1001/jamanetworkopen.2020.29256.

12-Knight M, Bunch K, Vousden N, Morris E, Simpson N, Gale C, O'Brien P, Quigley M, Brocklehurst P, Kurinczuk JJ; UK Obstetric Surveillance System 
SARS-CoV-2 Infection in Pregnancy Collaborative Group. Characteristics and outcomes of pregnant women admitted to hospital with confirmed SARSCoV-2 infection in UK: national population based cohort study. BMJ. 2020 Jun 8;369:m2107. doi: 10.1136/bmj.m2107.

13-Yan J, Guo J, Fan C, Juan J, Yu X, Li J, Feng L, Li C, Chen H, Qiao Y, Lei D, Wang C, Xiong G, Xiao F, He W, Pang Q, Hu X, Wang S, Chen D, Zhang Y, Poon LC, Yang H. Coronavirus disease 2019 in pregnant women: a report based on 116 cases. Am J Obstet Gynecol. 2020 Jul;223(1):111.e1-111.e14. doi: 10.1016/j.ajog.2020.04.014.

14-Di Mascio D; WAPM (The World Association of Perinatal Medicine) working group on COVID-19. Maternal and Perinatal Outcomes of Pregnant Women with SARS-COV-2 infection. Ultrasound Obstet Gynecol. 2020 Sep 14. doi: 10.1002/uog.23107.

15-Steegers EA, von Dadelszer P, Duvekot JJ, Pijnenborg R. Pre-eclampsia. Lancet 2020;376:631-44.

16-Coronado-Arroyo JC, Concepción-Zavaleta MJ, Zavaleta-Gutiérrez FE, Concepción-Urteaga LA. Is COVID-19 a risk factor for severe preeclampsia? Hospital experience in a developing country. Eur J Obstet Gynecol Reprod Biol. 2021 Jan;256:502-503. doi: 10.1016/j.ejogrb.2020.09.020.

17-Mendoza M, Garcia-Ruiz I, Maiz N, Rodo C, Garcia-Manau P, Serrano B, Lopez-Martinez RM, Balcells J, Fernandez-Hidalgo N, Carreras E, Suy A. Pre-eclampsia-like syndrome induced by severe COVID-19: a prospective observational study. BJOG. 2020 Oct;127(11):1374-1380. doi: 10.1111/14710528.16339. 
18-Beys-da-Silva WO, da Rosa RL, Santi L, Tureta EF, Terraciano PB, Guimarães JA, Passos EP, Berger M. The risk of COVID-19 for pregnant women: Evidences of molecular alterations associated with preeclampsia in SARS-CoV-2 infection. Biochim Biophys Acta Mol Basis Dis. 2020 Nov 1:165999. doi: 10.1016/j.bbadis.2020.165999.

19-Menezes MO, Takemoto MLS, Nakamura-Pereira M, Katz L, Amorim MMR, Salgado HO, Melo A, Diniz CSG, de Sousa LAR, Magalhaes CG, Knobel R, Andreucci CB; Brazilian Group of Studies for COVID-19, Pregnancy. Risk factors for adverse outcomes among pregnant and postpartum women with acute respiratory distress syndrome due to COVID-19 in Brazil. Int J Gynaecol Obstet. 2020 Dec;151(3):415-423. doi: 10.1002/ijgo.13407

20-Chen L, Li Q, Zheng D, Jiang H, Wei Y, Zou L, Feng L, Xiong G, Sun G, Wang H, Zhao Y, Qiao J. Clinical Characteristics of Pregnant Women with Covid-19 in Wuhan, China. N Engl J Med. 2020 Jun 18;382(25):e100. doi: 10.1056/NEJMc2009226.

21-Ahlberg M, Neovius M, Saltvedt S, Söderling J, Pettersson K, Brandkvist C, Stephansson O. Association of SARS-CoV-2 Test Status and Pregnancy Outcomes. JAMA. 2020 Sep 23;324(17):1782-5. doi: 10.1001/jama.2020.19124. 
medRxiv preprint doi: https://doi.org/10.1101/2021.06.03.21258328; this version posted June 6, 2021. The copyright holder for this preprint (which was not certified by peer review) is the author/funder, who has granted medRxiv a license to display the preprint in perpetuity.

\section{TABLE 1}

Demographic, clinical and laboratories characteristics of pregnant women infected by SARS-CoV-2.

\begin{tabular}{|c|c|c|}
\hline VARIABLE & & $(95 \% \mathrm{Cl})$ \\
\hline Maternal age, year(SD) & $26.4(6.8)$ & -- \\
\hline Gestational age at diagnosed, wk(SD) & $34.5(5.5)$ & -- \\
\hline Abortion $\mathrm{n}(\%)$ & $11(4.3)$ & $2.4-7.6$ \\
\hline Diagnosed second trimester, $\mathrm{n}(\%)$ & $26(10.7)$ & $7.4-15.3$ \\
\hline Diagnosed third trimester, $\mathrm{n}(\%)$ & $216(89.3)$ & $84.7-92.6$ \\
\hline Nulliparaous, $\mathrm{n}(\%)$ & $75(29.6)$ & $24.4-35.5$ \\
\hline Twins, $n(\%)$ & $6(2.4)$ & $1.1-5.1$ \\
\hline $\mathrm{BMI}(\mathrm{SD}), \mathrm{kg} / \mathrm{m}^{2}$ & $28.4(5.5)$ & -- \\
\hline BMI over $30 \mathrm{~kg} / \mathrm{m}^{2}, \mathrm{n}(\%)$ & $63(24.9)$ & -- \\
\hline Chronic hypertension, $\mathrm{n}(\%)$ & $9(3.6)$ & $1.9-6.6$ \\
\hline Pulmonary disease, $\mathrm{n}(\%)$ & $14(5.5)$ & 3.3-9.1 \\
\hline Collagenopathy, $\mathrm{n}(\%)$ & $3(1.2)$ & $0.4-3.4$ \\
\hline Heart disease, $\mathrm{n}(\%)$ & $2(0.8)$ & $0.2-2.8$ \\
\hline Severe allergy, $\mathrm{n}(\%)$ & $4(1.6)$ & $0.6-4.0$ \\
\hline Clinical symptoms, $n(\%)$ & 144(56.9) & $50.8-62.9$ \\
\hline Fever, $\mathrm{n}(\%)$ & $91(36.0)$ & $30.3-42.1$ \\
\hline Cough, $\mathrm{n}(\%)$ & $63(24.9)$ & $20.0-30.6$ \\
\hline Shortness of breath, $\mathrm{n}(\%)$ & $42(16.6)$ & $12.5-21.7$ \\
\hline General discomfort, $\mathrm{n}(\%)$ & $37(14.6)$ & $10.8-19.5$ \\
\hline Headache, $n(\%)$ & $36(14.2)$ & $10.5-19.1$ \\
\hline Myalgia, $\mathrm{n}(\%)$ & $21(8.3)$ & $5.5-12.4$ \\
\hline Runny nose, $\mathrm{n}(\%)$ & $16(6.3)$ & $3.9-10.0$ \\
\hline Anosmia, $n(\%)$ & $8(3.2)$ & $1.6-6.1$ \\
\hline Diarrhea, $\mathrm{n}(\%)$ & $6(2.4)$ & $1.1-5.1$ \\
\hline Ageusia, $n(\%)$ & $4(1.6)$ & $0.6-4.0$ \\
\hline $\begin{array}{l}\text { Maternal White-cell count }<4 \times \\
10^{-9} / \text { liter, } \mathrm{n}(\%)\end{array}$ & $8(3.2)$ & $1.6-6.1$ \\
\hline $\begin{array}{l}\text { Maternal lymphocyte count }<1.0 \times \\
10^{-9} / \text { liter, } \mathrm{n}(\%)\end{array}$ & $67(26.5)$ & $21.4-32.2$ \\
\hline
\end{tabular}




\section{TABLE 2}

Therapy prescribed and maternal outcomes to pregnant women infected by SARSCoV-2

\begin{tabular}{|l|c|c|}
\hline Mother antibiotics, $\mathrm{n}(\%)$ & $38(15.0)$ & $11.1-19.9$ \\
\hline Mother hydroxychloroquine, $\mathrm{n}(\%)$ & $10(4.0)$ & $2.2-7.1$ \\
\hline Mother lopinavir-ritonavir, $\mathrm{n}(\%)$ & $5(2.0)$ & $0.9-4.6$ \\
\hline Mild forms, $\mathrm{n}(\%)$ & $227(89.7)$ & $85.5-92.9$ \\
\hline Severe forms, $\mathrm{n}(\%)$ & $26(10.3)$ & $7.1-14.6$ \\
\hline Mother Intensive care unit admission, $\mathrm{n}(\%)$ & $17(6.7)$ & $4.2-10.5$ \\
\hline Mother Endotracheal intubation, $\mathrm{n}(\%)$ & $15(5.9)$ & $3.6-9.6$ \\
\hline Maternal death, $\mathrm{n}(\%)$ & $4(1.6)$ & $0.6-4.0$ \\
\hline
\end{tabular}


TABLE 3

Obstetrics and clinical outcomes of neonates born from women infected by SARSCoV-2 *.

\begin{tabular}{|c|c|c|}
\hline & & $(95 \% \mathrm{Cl})$ \\
\hline Gestational age at delivery, wk(SD) & $37.2(3.3)$ & -- \\
\hline Pre-eclampsia, n(\%) & $34(15.4)$ & $11.2-20.7$ \\
\hline Gestational hypertension, $\mathrm{n}(\%)$ & $13(5.9)$ & $3.5-9.8$ \\
\hline Gestational diabetes, $\mathrm{n}(\%)$ & $6(2.7)$ & $1.3-5.8$ \\
\hline Normal vaginal delivery, $\mathrm{n}(\%)$ & $93(42.1)$ & $35.8-48.7$ \\
\hline $\begin{array}{l}\text { Cesarean delivery, } \mathrm{n}(\%) \\
\text { Indicated by COVID-19, } \mathrm{n}(\%)\end{array}$ & $\begin{array}{l}128(57.9) \\
13(10.2)\end{array}$ & $\begin{array}{l}51.3-64.2 \\
6.0-16.6\end{array}$ \\
\hline Preterm delivery < 37 weeks, $n(\%)$ & $59(26.7)$ & $21.3-32.9$ \\
\hline $\begin{array}{ll}\text { Small-for-gestational } & \text { age/fetal- } \\
\text { growth restriction, } n(\%) & \end{array}$ & $27(12.2)$ & $8.5-17.2$ \\
\hline $\begin{array}{l}\text { Premature rupture of membrane, } \\
\mathrm{n}(\%)\end{array}$ & $18(8.1)$ & $5.2-12.5$ \\
\hline Birth weight g (SD) & $2894.0(769.4)$ & -- \\
\hline APGAR 1 minute (IQR) & $8(8-9)$ & -- \\
\hline APGAR 5 minute (IQR) & $8(8-9)$ & -- \\
\hline Neonatal pneumonia, $\mathrm{n}(\%)$ & $5(2.3)$ & $1.0-5.2$ \\
\hline Neonatal COVID-19, $\mathrm{n}(\%)$ & $1(0.5)$ & $0.1-2.5$ \\
\hline Perinatal deaths, $\mathrm{n}(\%)$ & $12(5.3)$ & $3.0-9.0$ \\
\hline Intrauterine fetal death, $\mathrm{n}(\%)$ & $7(3.1)$ & $1.5-6.2$ \\
\hline Neonatal death, $\mathrm{n}(\%)$ & $5(2.2)$ & $1.0-5.1$ \\
\hline
\end{tabular}

${ }^{*}$ Neonates $\mathrm{N}=227$ (6 Twin, 7 fetal deaths) 